varieties, breeding and the effect of environmental conditions. The following chapters deal with the production of quality planting materials, field culture, soil conditions, especially in their nutritive aspects, plantation management and yield. Other chapters are devoted to diseases and pests, of which there is no scarcity. There are also interesting and useful chapters on the tapping of the plant for its juice, curiosities or abnormalities in the development of the plant, and the utilization of its many and varied products. In the final chapter, the many outstanding problems in contemporary coconut research are discussed. In attempts to improve the industry, it need scarcely be said that the introduction of varieties and strains, and a considerable breeding programme, occupy an important place.

The book is very fully documented and well illustrated, some of the coloured plates and photographs being of very good quality indeed. It is hard to avoid the impression that research on the coconut palm is by no means as advanced as it ought to be; but what is known is faithfully presented in the volume under review.

C. W. WARDLAW

\section{HORMONES IN CRUSTACEANS}

\section{Endocrine Control in Crustaceans}

By David B. Carlisle and Sir Francis Knowles, Bart. (Cambridge Monographs on Experimental Biology, No. 10.) Pp. vii $+120+5$ plates. (Cambridge: At the University Press, 1959.) 21s. net.

COMPACT books, along with compact cars, pro4 vide a welcome relief in some of the more crowded parts of this world. Limited size, but not this alone, contributes to the popularity of the series of monographs of which "Endocrine Control in Crustacoans" is Number 10 . Dealing mainly with developments of the past ten years, this book discusses the phenomenon of neurosecretion and contributions to this relatively new field resulting from studies on the Crustacea. Neurones, modified for secretion, have been found in most animals that have been examined, but their organization into systems and the roles of the neurohormones that these systems produce are best understood in the vertebrates, insects and Crustacea. The last-named have three principal types of neurosecretory systems : the socalled sinus gland system, the post-commissural organ system and the pericardial organ system. In each of these, the neurones end on blood spaces and release their products into the circulation, where they are distributed throughout the body to control a wide variety of physiological processes. In this book one finds a discussion of the anatomy of these systems, including fine structure, and the chemical nature and physiological actions of the hormones that they produce.

Since the sinus glands have been shown to consist of groups of nerve endings, modified for storage and release, only the rather recently described $\mathrm{Y}$ organs remain as 'true' endocrine glands in the Crustacea. Their role in the control of moulting and their obvious relation to the prothoracic glands of insects are discussed.

The authors point out some of the confusion that surrounds the identification and naming of components of the $\mathrm{X}$ organ-sinus gland system. This arises, in part, from the incomplete evidence that the 'sensory-pore $\mathrm{X}$ organ' is an important endocrine structure and the apparent desire on the part of some workers to link one important group of neurosecretory cell bodies of the eyestalk, the medulla terminalis ganglionic $\mathrm{X}$ organ, with the original $\mathrm{X}$ organ complex of Hanström. This matter and others pertaining to crustacean endocrines will be clarified in the next decade by workers who will find this compact book a most helpful résumé of our current understanding of this field.

J. H. Wexsh

\section{RENAISSANCE ANATOMY}

A Short Introduction to Anatomy (Isagogae Breves) By Jacopo Berengario da Carpi. Translated with an Introduction and Historical Notes by L. R. Lind, and with Anatomical Notes by Paul G. Roofe. Pp. xi+227. (Chicago: University of Chicago Press; London : Cambridge University Press, 1959.) 37s. 6d. net.

TACOPO BARIGAZZI (c. 1460-1530), or, as he is traditionally known, Berengario da Carpi, was a near-contemporary of Leonardo da Vinci, whose magnificent amateur exploration of the human body stands in fascinating contrast to the work of this competent but uninspired professional. Berengario was a successful physician among the tough characters of Renaissance Italy. Whatever the merits of his medical practice (he cured Lorenzo de' Medici of a skull wound but Cellini reports that he crippled scores of wealthy syphilitics in Rome), he was vigorous, grasping and unscrupulous. His learning in medicine was of the old fashion rather than the new, and his anatomical nomenclature was full of Arabisms which the humanists were soon to replace by Greek terms. In this and other ways Berengario denotes anatomy in transition from the medieval world to the more modern one of Gunther, Sylvius, Vesalius and other expositors of the genuine Galen.

Nevertheless, Berengario is an important figure in the history of anatomy, one who would have been more significant if the pace had not so rapidly accelerated in the next generation. He was certainly experienced, even though his claim to have dissected hundreds of bodies must refer to autopsies rather than scientific dissections. New discoveries and important corrections of traditional errors are attributed to him, and he seems to have performed some original experiments to study the working of the body. His illustrations, though few, are superior to all preceding ones. If these and his text pale in comparison with those of Vesalius twenty years later, Berengario and others show that the study of anatomy was proceeding actively long before Vesalius took up the scalpel.

Berengario's chief work was a Commentary (1521) on the fourteenth-century anatomy of Mundinus. In the following year he published a shorter compendium ("Isagogae breves") of human anatomy. This has now been translated by Dr. Lind, who ten years ago printed an English version of Vesalius' "Epitome". Berengario writes as a practical guide to dissection; thus the student is instructed : "Leave the left kidney in its place until the spermatic vessels are examined. Cut the right kidney in its hollow through the middle, examining the place of the vein and of the great artery itself. ..." Anatomy is accompanied by brief remarks on the temperaments, functions and diseases of the structures described. The 